\title{
Perbedaan Bentuk Kekerasan dalam Rumah Tangga Ditinjau dari Usia saat Menikah dan Tingkat Pendidikan
}

\author{
Nanda Rizki Rahmita, Haiyun Nisa \\ Program Studi Psikologi, Fakultas Kedokteran, Universitas Syiah Kuala, Indonesia \\ e-mail : haiyunnisa@unsyiah.ac.id
}

\begin{abstract}
Domestic violence is a global problem found in all cultures and communities. Perpetrators or victims of domestic violence come from different backgrounds, such as those from all ages, ethnicities, income levels, or education levels. Domestic violence victims can experience various types of violence including psycho-physical violence and control violence. Age at marriage and level of education affect the types of domestic violence experienced by victims. The research method used is a quantitative method with a comparative research on 86 subjects who experienced domestic violence. Data analysis used Crosstab and Chi-Square Test for Independence analysis which showed the significance value of the form of domestic violence. These results indicate that there are no differences in forms of domestic violence in terms of age at marriage and education level. Viewed from age at marriage and education level, the subjects of the study experienced more control violence compared to psycho-physical violence.
\end{abstract}

Keywords: types of domestic violence, age at marriage, level of education

\begin{abstract}
Abstrak
Kekerasan dalam rumah tangga (KDRT) merupakan suatu masalah global yang terdapat di semua budaya dan masyarakat. Pelaku ataupun korban KDRT berasal dari latar belakang yang berbeda, baik dari segi usia, etnis, tingkat pendapatan, atau tingkat pendidikan. Korban KDRT dapat mengalami berbagai bentuk kekerasan diantaranya psycho-physical violence dan control violence. Usia saat menikah dan tingkat pendidikan memengaruhi bentuk KDRT yang dialami oleh korban. Penelitian ini bertujuan untuk melihat perbedaan bentuk KDRT ditinjau dari usia saat menikah dan tingkat pendidikan. Penelitian menggunakan metode kuantitatif jenis komparasi pada 86 subjek yang mengalami KDRT. Analisis data menggunakan analisis Crosstab dan Chi-Square Test for Independence yang menunjukkan hasil bahwa tidak terdapat perbedaan bentuk kekerasan dalam rumah tangga ditinjau dari usia saat menikah dan tingkat pendidikan. Ditinjau dari usia saat menikah dan tingkat pendidikan, subjek penelitian lebih banyak mengalami control violence dibandingkan dengan psycho-physical violence.
\end{abstract}

Kata Kunci: bentuk kekerasan dalam rumah tangga, usia saat menikah, tingkat pendidikan

\section{Pendahuluan}

Pernikahan atau perkawinan merupakan salah satu tugas perkembangan yang idealnya menawarkan keintiman, persahabatan, kasih sayang, pemenuhan kebutuhan seksual, dan persahabatan (Papalia, Strens, Feldman, \& Camp, 2002). Namun dalam perjalanan perkawinan, pasangan tidak sepenuhnya dapat merasakan kebahagiaan, saling mencintai, dan saling menyayangi, melainkan terdapat juga rasa ketidaknyamanan, tertekan, kesedihan, saling takut, serta benci di antara pasangan. Hal ini diindikasikan dengan masih dijumpainya sejumlah rumah tangga yang bermasalah, bahkan terjadi beragam kekerasan dalam rumah tangga atau yang biasa disebut KDRT (Wahab, 2006).

Kekerasan dalam rumah tangga merupakan suatu permasalahan yang terus tumbuh dan terjadi di banyak negara (Aghakhani, Nia, Moosavi, Eftekhari, Bahrami, \& Nikoonejad, 2015). Penelitian yang dilakukan di 50 negara di dunia, menunjukkan bahwa antara 10-60\% perempuan yang pernah menikah atau 
berpasangan telah mengalami kekerasan fisik dari pasangannya. Lebih lanjut, penelitian ini juga menyebutkan bahwa perempuan lebih cenderung diserang, dilukai, diperkosa, atau dibunuh oleh pasangan dibandingkan dengan orang lain (Garcia-Moreno, Jansen, Ellsberg, Helse, \& Watts, 2006). Menurut Hogan (2016) kekerasan dalam rumah tangga tidak hanya dialami oleh perempuan, namun lakilaki juga bisa menjadi korbannya. Diberitakan oleh Sindonews.com lebih dari 700.000 pria di Inggris dilaporkan menjadi korban kekerasan dalam rumah tangga sepanjang tahun 2017. Jenis kekerasan yang dilaporkan lebih mengarah pada tindakan pengendalian, pemaksaan, ancaman, kekerasan, atau pelecehan ("Lebih dari 700.000 pria di Inggris jadi korban KDRT, 135 diantaranya tewas dibunuh," 2017).

Hollin dan Bloxsom (dalam Abolmaali, Saberi, \& Saber, 2014) menjelaskan pengertian kekerasan dalam rumah tangga yang kadang-kadang disebut juga sebagai kekerasan keluarga merupakan kekerasan antar pribadi, termasuk perilaku dan tindakan agresif antara anggota keluarga dan itu mungkin terjadi antara pasangan, anak-anak, orang tua, saudara perempuan dan atau saudara laki-laki.

Lebih lanjut Abolmaali dkk. (2014) mengemukakan dua dimensi dari kekerasan dalam rumah tangga yaitu: pertama, psychophysical violence yang di dalamnya termasuk kekerasan fisik dan kekerasan psikologis. Kedua, control violence yang di dalamnya termasuk kekerasan seksual, kekerasan ekonomi, serta pemaksaan.

Kekerasan fisik terhadap pasangan termasuk tindakan seperti serangan dengan senjata, mendorong, meninju, menampar, menendang, dan melemparkan benda pada pasangan, hal ini dapat terjadi secara bilateral antara pasangan. Bentuk kekerasan lainnya adalah kekerasan psikologis yang juga dianggap sebagai pelecehan emosional yang ditandai oleh beberapa dimensi termasuk perilaku mengancam baik implisit maupun eksplisit, merendahkan citra diri atau harga diri, menahan hubungan emosional dan pengasuhan secara pasifagresif, membatasi wilayah personal dan kebebasan.

Kekerasan finansial atau ekonomi yang termasuk perilaku seperti mempertahankan kendali atas keuangan, menciptakan penghalang untuk membagi uang, menahan akses kepada uang, membuat korban secara finansial tergantung, tidak membiarkan korban bekerja, kontrol pendapatan dan mengambil kartu kredit atau uang pasangan, menekan korban karena menghabiskan uang, dan penyalahgunaan keuangan oleh pelaku. Kekerasan finansial ini juga termasuk di dalamnya tidak menafkahi korban yang sebenarnya di bawah tanggungan pelaku. Selanjutnya ada kekerasan seksual yang di dalamnya termasuk hubungan seksual yang tidak terduga seperti perilaku seksual yang keras atau tidak biasa dan kasar, aktivitas seksual yang dipaksa, serta tekanan untuk melakukan hubungan seks.

Catatan Tahunan Komisi Nasional Perempuan Indonesia tahun 2017 memaparkan bahwa kekerasan terhadap perempuan yang paling menonjol adalah kekerasan dalam rumah tangga yang mencapai angka $75 \%$ yaitu sebanyak 10.205 kasus. Jumlah kasus kekerasan dalam rumah tangga berdasarkan jenis kekerasan yang terjadi di Indonesia pada tahun 2017 disajikan pada tabel 1 .

Tabel 1

Jumlah Kasus Kekerasan dalam Rumah Tangga Dilihat dari Jenis Kekerasan

\begin{tabular}{lcc}
\hline \multirow{2}{*}{ Jenis Kekerasan } & \multicolumn{2}{c}{ Jumlah } \\
\cline { 2 - 3 } & (Kasus) & (Persentase) \\
\hline Fisik & 4.281 & $42 \%$ \\
Seksual & 3.495 & $34 \%$ \\
Psikologis & 1.451 & $14 \%$ \\
Ekonomi & 978 & $10 \%$ \\
\hline
\end{tabular}

Sumber: Lembar catatan tahunan Komisi Nasional Perempuan Indonesia tahun 2017

Berdasarkan tabel 1 dapat diketahui bahwa jenis kekerasan yang paling menonjol di Indonesia pada tahun 2017 adalah 
kekerasan fisik, kemudian diikuti kekerasan seksual, kekerasan psikologis, dan kekerasan ekonomi atau penelantaran rumah tangga. Aceh merupakan salah satu provinsi di Indonesia yang memiliki permasalahan kekerasan dalam rumah tangga. Banda Aceh merupakan kabupaten/kota dengan kasus kekerasan dalam rumah tangga tertinggi di Aceh dengan jumlah kasus sebanyak 90 kasus, kemudian disusul oleh Aceh Utara sejumlah 62 kasus (Bintang, 2018).

Kebanyakan korban kekerasan dalam rumah tangga berasal dari negara yang memiliki ekonomi rendah (Banerjee, Ferrara, \& Orozco, 2019). Namun, terlepas dari hal tersebut, siapapun dapat menjadi korban kekerasan dalam rumah tangga dan umumnya disebabkan karena relasi kuasa (ketidakseimbangan kekuasaan) dan kontrol. Pelaku ataupun korban kekerasan dalam rumah tangga berasal dari latar belakang yang berbeda, seperti berasal dari segala usia, etnis, tingkat pendapatan, atau tingkat pendidikan (Ashcroft, Deborah, \& Hart, 2004).

Penelitian yang dilakukan oleh GarciaMoreno dkk. (2006) menemukan bahwa wanita muda, khususnya usia 15-19 tahun, memiliki tingkat risiko yang tinggi untuk mengalami kekerasan fisik dan seksual, atau keduanya pada semua keadaan. Secara lebih lanjut, Garcia-Moreno dkk. (2006) memaparkan bahwa $48 \%$ wanita pada masyarakat kota Bangladesh yang berusia 15-19 tahun melaporkan mengalami kekerasan fisik dan seksual, atau keduanya. Persentase ini jauh lebih tinggi dibandingkan persentase wanita usia 45-49 tahun yang melaporkan mengalami kekerasan fisik dan seksual, atau keduanya, yaitu sebanyak $10 \%$. Hal yang sama juga ditemukan pada wanita kota Peru, yaitu sebanyak $41 \%$ wanita usia 15-19 tahun dibandingkan wanita usia 45-49 tahun sebanyak $8 \%$ yang mengalami kekerasan fisik dan seksual, atau keduanya.

Sejalan dengan penelitian di atas, penelitian yang dilakukan oleh Mantiri, Siwu, dan Kristanto (2013) menunjukkan bahwa kekerasan dalam rumah tangga banyak terjadi pada perempuan yang menikah usia dini (menikah muda) dibandingkan dengan perempuan yang menikah pada usia lebih dewasa. Penelitian ini juga menunjukkan kasus kekerasan dalam rumah tangga banyak terjadi pada usia 15-20 tahun (68.52\%), kemudian diikuti oleh usia 21-25 tahun (24.07\%), rentang usia 26-30 tahun $(5.55 \%)$, dan rentang usia lebih atau sama dengan 30 tahun (1.86\%). Menurut Lujeng, Sukohar, Hutaharuk, dan Putra (2016) pernikahan dini merupakan salah satu faktor terjadinya kekerasan dalam rumah tangga. Batas usia untuk menikah di Indonesia telah diatur dalam Undang-Undang Republik Indonesia Nomor 1 Tahun 1974, Pasal 7, Ayat 1 yaitu batas minimal usia perempuan 16 tahun dan laki-laki 19 tahun.

Faktor lainnya yang memengaruhi kekerasan dalam rumah tangga adalah tingkat pendidikan. Penelitian Word Health Organization (WHO) menemukan hubungan negatif antara tingkat pendidikan dengan kekerasan. Semakin tinggi pendidikan berasosiasi dengan rendahnya tingkat kekerasan di Brazil, Namibia, Peru, Thailand, dan Republik Tanzania (GarciaMoreno dkk., 2006). Hal serupa dijelaskan oleh Flake (2005) bahwa wanita harus mengangkat statusnya melalui pendidikan. Lebih lanjut, penelitian Flake (2005) menunjukkan bahwa tingkat pendidikan yang rendah menjadi faktor risiko mengalami kekerasan dalam rumah tangga. Penelitian yang dilakukan oleh Pun (2013) pada 66 keluarga di Nepal menemukan hal serupa, bahwa pendidikan dan ekonomi yang rendah menjadi alasan utama terjadinya kekerasan dalam rumah tangga. Lebih lanjut, penelitian ini juga mengungkapkan bahwa mayoritas subjek penelitian setuju bahwa pendidikan merupakan faktor yang paling penting untuk mencegah kekerasan dalam rumah tangga. Pusat Pelayanan Terpadu Perlindungan Perempuan dan Anak (P2TP2A) melakukan penelitian terhadap mitranya pasca terminasi dari layanan yang diberikan pada tahun 2017 di Aceh menunjukkan bahwa angka kasus kekerasan dalam rumah tangga terbanyak 
dialami oleh perempuan dengan tingkat pendidikan akhir SLTA sederajat (52\%), SD sederajat (24\%), perguruan tinggi (22\%), dan pendidikan akhir SLTP (2\%).

Berbeda dengan penelitian sebelumnya, penelitian yang dilakukan oleh Dafeni, Mawarni, Nugroho, dan Dharmawan (2017) pada 100 orang wanita usia subur menunjukkan bahwa wanita dengan pendidikan lanjut atau pendidikan tinggi lebih banyak mengalami kekerasan dalam rumah tangga dibandingkan dengan perempuan yang memiliki tingkat pendidikan lebih rendah. Sejalan dengan penelitian Dafeni dkk. (2017), penelitian yang dilakukan oleh Wiyarsi, Salirawati, dan Sulistyowati (2012) pada 200 wanita karier di lima kabupaten yang terletak di Daerah Istimewa Yogyakarta mengemukakan bahwa terdapat sebagian kecil wanita karier yang berprofesi sebagai guru atau dosen yang mengalami kekerasan dalam rumah tangga.

Penelitian Nikparvar, Stith, Anderson, dan Panaghi (2018) menemukan bahwa bagi wanita, pendidikan yang rendah berhubungan dengan laporan mereka terkait tingginya kejadian kekerasan psikologis dan agresi fisik. Penelitian Aghakhani dkk. (2015) menunjukkan bahwa kekerasan fisik terjadi lebih banyak pada wanita yang memiliki pendidikan yang rendah dibandingkan dengan wanita yang berpendidikan lebih tinggi. Hal ini bisa saja terjadi karena perempuan yang berpendidikan tinggi mempunyai koping yang lebih efektif dan situasi ekonomi yang lebih baik. Lebih lanjut, berdasarkan penelitian Anderberg, Rainer, Wadsworth, dan Wilson (2015), tingginya pengangguran berhubungan dengan meningkatnya kekerasan dalam rumah tangga. Laki-laki dan perempuan yang tidak bekerja lebih berisiko mengalami kekerasan dalam rumah tangga.

Berdasarkan data dan hasil penelitian yang telah dipaparkan di atas, terdapat perbedaan hasil penelitian dan fenomena terkait bentuk kekerasan dalam rumah tangga berdasarkan usia subjek saat menikah dan tingkat pendidikan subjek. Dimana, terdapat hasil penelitian yang menyatakan subjek dengan tingkat pendidikan yang rendah dan menikah pada usia muda berasosiasi dengan bentuk kekerasan fisik. Namun terdapat hasil penelitian lainnya yang menyatakan hal berbeda. Penelitian ini bertujuan untuk mengetahui perbedaan bentuk kekerasan dalam rumah tangga ditinjau dari usia subjek pada saat menikah dan tingkat pendidikan di Kota Banda Aceh. Hipotesis yang dirumuskan dalam penelitian ini adalah terdapat perbedaan bentuk kekerasan dalam rumah tangga ditinjau dari usia saat menikah dan tingkat pendidikan.

\section{Metode Penelitian}

Penelitian ini menggunakan desain penelitian kuantitatif dengan jenis penelitian komparatif untuk membandingkan bentuk kekerasan yang dialami subjek dalam rumah tangga, berdasarkan perbedaan usia saat menikah serta tingkat pendidikan mereka.

Populasi dalam penelitian ini adalah laki-laki dan perempuan yang mengalami kekerasan dalam rumah tangga di Kota Banda Aceh. Adapun karakteristik sampel khusus dalam penelitian ini adalah berstatus menikah, laki-laki atau perempuan, usia minimal 16 tahun saat menikah, berdomisili di Banda Aceh, dan mengalami kekerasan dalam rumah tangga. Pengambilan sampel dalam penelitian ini menggunakan metode non probability sampling dengan teknik incidental sampling, artinya peneliti akan mengambil individu-individu yang secara kebetulan dijumpai dan sesuai dengan karakteristik sampel penelitian. Jumlah sampel dalam penelitian ini sebanyak 86 orang. Jumlah sampel ini sudah memenuhi jumlah sampel minimum dalam penelitian kuantitatif yaitu 30 responden (Idrus, 2009).

Skala yang digunakan untuk mengukur kekerasan dalam rumah tangga dalam penelitian ini adalah modifikasi dari Domestic Violence Questionnaire yang dikembangkan oleh Abolmaali dkk. (2014) yang terdiri dari 42 butir pernyataan favorable. Menurut Azwar (2013) peneliti 
dapat menyusun skala berupa pernyataan dalam bentuk favorable dan unfavorable atau salah satu dari keduanya. Abolmaali dkk. (2014) menyusun Domestic Violence Questionnaire berdasarkan pengertian kekerasan dalam rumah tangga yang dikemukakan oleh Hollin dan Bloxsom pada tahun 2007, dimana pengertian ini dibangun berdasarkan teori agresivitas.

Domestic Violence Questionnaire menggunakan skala likert dengan rentang skala 04 dengan ketentuan sebagai berikut: $0=$ sama sekali tidak sesuai untuk pasangan saya, $1=$ sedikit sesuai untuk pasangan saya, $2=$ cukup sesuai untuk pasangan saya, $3=$ sesuai untuk pasangan saya, $4=$ sangat sesuai untuk pasangan saya. Contoh pernyataan dalam Domestic Violence Questionnaire diantaranya: "Dia berteriak pada saya" dan "Dia mengendalikan perilaku dan tindakan saya".

Penggunaan Domestic Violence Questionnaire dalam penelitian ini karena dimensi yang diukur dalam skala ini sesuai dengan pengertian kekerasan dalam rumah tangga berdasarkan Undang-Undang nomor 23 tahun 2004 yaitu memuat kekerasan fisik, kekerasan psikologis, kekerasan seksual, serta kekerasan ekonomi.

Abolmaali dkk. (2014) menguji validitas Domestic Violence Questionnaire menggunakan jenis validitas konten, validitas konstruk, validitas kriteria, dan validitas diferensial. Nilai konsistensi Domestic Violence Questionnaire berdasarkan validitas konten adalah .961. Validitas konstruk dalam penelitian ini diukur menggunakan analisis faktor dan mendapatkan nilai sebesar $25.47 \%$ dari total variasi tes. Korelasi skor Domestic Violence Questionnaire dengan Hudson's Life Quality Questionnaire yang merupakan alat ukur kualitas hidup bagi pasangan, alat ukur ini digunakan sebagai kriteria eksternal untuk menguji validitas kriteria. Dari hasil uji validitas ini didapatkan korelasi antara Domestic Violence Questionnaire dengan Hudson's Life Quality Questionnaire sebesar -.625. Terakhir, berdasarkan pengukuran validitas diferensial, Domestic Violence Questionnaire memiliki kemampuan untuk membedakan individu dengan kekerasan dalam rumah tangga dengan individu yang tidak mengalaminya. Berdasarkan uji validitas yang telah dilakukan menggambarkan bahwa Domestic Violence Questionnaire dapat mengukur apa yang hendak diukur yaitu kekerasan dalam rumah tangga.

Adapun uji validitas yang digunakan dalam penelitian ini adalah jenis validitas isi (content validity). Validitas isi adalah validitas yang diestimasi melalui pengujian terhadap isi tes dengan analisis rasional oleh panel yang berkompeten atau melalui expert review (Azwar, 2013). Proses expert judgement dalam penelitian ini melibatkan dua orang psikolog klinis dan satu orang pakar Psikologi Sosial.

Domestic Violence Questionnaire telah diuji reliabilitas menggunakan uji reliabilitas internal consistency dan test-retest oleh Abolmaali dkk. (2014). Pengujian internal consistency menghasilkan nilai cronbach alpha sebesar .915 dan berdasarkan uji testretest perbandingan nilai $\mathrm{r}$ sebesar .987 ( $\mathrm{r}=$ 987). Hasil pengujian reliabilitas ini menunjukkan Domestic Violence Questionnaire merupakan alat ukur yang reliabel.

Metode estimasi yang digunakan dalam penelitian ini adalah estimasi penyajian tunggal, yang mana estimasi pengolahan data yang digunakan koefisien reliabilitas (alpha Cronbach). Berdasarkan pengujian reliabilitas ini, Domestic Violence Questionnaire memiliki nilai reliabilitas $(\alpha)$ senilai .877 . Indeks daya beda aitem kuesioner berkisar antara .068 - .687.

Teknik analisis data yang digunakan dalam penelitian ini adalah Crosstab dan Chi-Square Test for Independence. Analisis ini digunakan untuk melihat perbedaan dan membandingkan frekuensi atau proporsi kejadian yang terdapat pada variabel terikat terhadap seluruh kelompok yang dibandingkan. 


\section{Hasil Penelitian dan Pembahasan}

\section{Gambaran Sosiodemografi Subjek Penelitian}

Penelitian dilakukan pada 86 individu yang mengalami kekerasan dalam rumah tangga dan berdomisili di Kota Banda Aceh. Data demografi subjek dapat dilihat pada tabel 2.

Tabel 2

Data Demografi Subjek Penelitian

\begin{tabular}{|c|c|c|c|}
\hline Deskripsi & $\begin{array}{l}\text { Jumlah } \\
\text { Subjek }\end{array}$ & $\%$ & $\begin{array}{c}\text { Total } \\
(\%)\end{array}$ \\
\hline Jenis Kelamin & & & 100 \\
\hline Perempuan & 74 & 86.0 & \\
\hline Laki-laki & 12 & 14.0 & \\
\hline Tingkat Pendidikan & & & 100 \\
\hline Pendidikan & 39 & 45.3 & \\
\hline menengah & 47 & 54.7 & \\
\hline Pendidikan tinggi & & & \\
\hline Usia Saat Menikah & & & 100 \\
\hline 16-20 tahun & 24 & 27.9 & \\
\hline$\geq 21$ tahun & 62 & 72.1 & \\
\hline Usia & & & 98.8 \\
\hline $20-40$ & 56 & 65.1 & \\
\hline $41-65$ & 29 & 33.7 & \\
\hline Status Pekerjaan & & & 97.6 \\
\hline Mahasiswa & 2 & 2.3 & \\
\hline Bekerja & 50 & 58.1 & \\
\hline Tidak Bekerja & 32 & 37.2 & \\
\hline Jumlah Anak & & & 100 \\
\hline Tidak memiliki anak & 10 & 11.6 & \\
\hline 1 orang & 15 & 17.4 & \\
\hline 2 orang & 22 & 25.6 & \\
\hline 3 orang & 24 & 27.9 & \\
\hline 4 orang & 10 & 11.6 & \\
\hline 5 orang & 5 & 5.8 & \\
\hline Penghasilan & & & 89.5 \\
\hline$<\operatorname{Rp} 2.717 .750$ & 13 & 15.1 & \\
\hline$\geq \operatorname{Rp} 2.717 .750$ & 64 & 74.4 & \\
\hline
\end{tabular}

Berdasarkan data demografi subjek penelitian pada tabel 2, dapat diketahui bahwa subjek penelitian sebagian besar berjenis kelamin perempuan yaitu sebanyak 74 orang $(86.0 \%)$, sedangkan subjek berjenis kelamin laki-laki berjumlah 12 orang $(14.0 \%)$. Selain itu, subjek penelitian yang memiliki tingkat pendidikan tinggi, yaitu Diploma-1 (D-1), Strata-1 (S-1), dan Strata-2 (S-2), berjumlah 47 orang $(54.7 \%)$ dan selebihnya subjek berpendidikan menengah, yaitu SMP dan SMA, yang berjumlah 39 orang $(45.3 \%)$.

Kelompok subjek yang menikah pada usia di atas atau sama dengan 21 tahun $(\geq 21)$ merupakan yang paling banyak yaitu sejumlah 62 orang $(72.1 \%)$, sedangkan selebihnya subjek menikah pada rentang usia 16-20 tahun yaitu sebanyak 24 orang (27.9\%).

Untuk mengetahui bentuk kekerasan dalam rumah tangga yang dialami oleh subjek penelitian, peneliti telah melakukan analisis frekuensi dengan menggunakan uji Cross Tabs. Data untuk bentuk kekerasan dalam rumah tangga pada penelitian ini dikumpulkan dengan menggunakan Domestic Violence Questionnaire (DVQ). Kuesioner ini disusun berdasarkan dua dimensi yaitu psycho-physical violence dan control violence. Sebelumnya, jumlah dari masing-masing dimensi dari DVQ telah dihitung. Skor yang diperoleh kemudian dipisahkan berdasarkan nomor aitem masingmasing dimensi.

Tabel 3 menunjukkan penyebaran frekuensi masing-masing data sosiodemografi subjek pada bentuk kekerasan dalam rumah tangga. Berdasarkan usia saat menikah, kelompok yang memiliki frekuensi subjek terbesar berada pada bentuk kekerasan control violence, yaitu subjek yang menikah pada usia 21 tahun ke atas sebanyak 41 orang $(66.1 \%)$, dan yang menikah pada rentang usia 16-20 tahun sebanyak 17 orang $(70.8 \%)$ frekuensi subjek terendah yaitu pada bentuk kekerasan psycho-physical violence dengan jumlah subjek yang menikah pada usia 21 tahun ke atas sebanyak 21 orang (33.9\%), dan jumlah subjek yang menikah pada usia 16-20 tahun sejumlah 7 orang (29.9\%).

Data pada tabel 3 juga menggambarkan bahwa ditinjau dari tingkat pendidikan, bentuk kekerasan control violence juga masih mendominasi dengan jumlah subjek pada kelompok pendidikan menengah sebanyak 26 orang (66.7\%) dan kelompok pendidikan tinggi sebanyak 33 orang (70.2\%). Subjek yang mengalami kekerasan 
psycho-physical violence pada kelompok pendidikan menengah sejumlah 13 orang $(33.3 \%)$ dan subjek pada kelompok pendidikan tinggi sebanyak 14 orang $(29.8 \%)$.

Baik laki-laki ataupun perempuan lebih banyak mengalami control violence dengan jumlah masing-masing 9 orang $(75 \%)$ dan 50 orang $(67.6 \%)$, sedangkan yang mengalami psycho-physical violence yaitu sejumlah 3 orang $(25 \%)$ dan perempuan sebanyak 24 orang $(32.4 \%)$. Sama halnya dengan jenis kelamin, jika ditinjau dari usia subjek, bentuk kekerasan control violence juga mendominasi yaitu kelompok usia 20-40 tahun sebanyak 42 orang $(75 \%)$ dan kelompok usia 41-65 tahun sebanyak 17 orang $(58.6 \%)$. Untuk bentuk kekerasan psycho-physical violence, kelompok usia 2040 tahun yang mengalami kekerasan sebanyak 14 (25.0\%) dan kelompok usia 41- mahasiswa sebanyak 2 orang (100\%). Kelompok subjek tidak bekerja yang mengalami psycho-physical violence sebanyak 10 orang (31.3\%), kelompok bekerja sebanyak 17 (34\%), dan tidak ada kelompok mahasiswa yang mengalami psycho-physical violence.

Ditinjau dari jumlah anak, bentuk kekerasan control violence juga yang paling banyak dialami oleh subjek yaitu 9 orang (90\%) subjek yang tidak memiliki anak, 11 orang $(73.3 \%)$ subjek yang memiliki 1 anak, 13 orang $(59.1 \%)$ yang memiliki 2 anak, 15 orang $(62.5 \%)$ yang memiliki 3 anak, 8 orang $(80 \%)$ yang memiliki 4 anak, dan 3 orang (60\%) yang memiliki 5 anak. Sedangkan psycho-physical violence dialami oleh 1 orang (10\%) subjek yang tidak memiliki anak, 4 orang $(26.7 \%)$ subjek yang memiliki 1 anak, 9 orang (40.9\%) yang memiliki 2 anak, 9 orang (37.5\%) yang memiliki 3 anak,

Tabel 3

Penyebaran Frekuensi Faktor Sosiodemografi pada Bentuk kekerasan dalam Rumah Tangga

\begin{tabular}{lccc}
\hline \multirow{2}{*}{ Sosiodemografi } & \multirow{2}{*}{ Kategori } & \multicolumn{2}{c}{ Bentuk Kekerasan } \\
\cline { 2 - 3 } & & Psycho-Physical Violence & Control Violence \\
\hline Usia Saat Menikah & $16-20$ tahun & $7(29.2 \%)$ & $17(70.8 \%)$ \\
Tingkat Pendidikan & $\geq 21$ tahun & $21(33.9 \%)$ & $41(66.1 \%)$ \\
& Menengah & $13(33.3 \%)$ & $26(66.7 \%)$ \\
Jenis Kelamin & Tinggi & $14(29.8 \%)$ & $33(70.2 \%)$ \\
Usia & Laki-laki & $3(25 \%)$ & $9(75 \%)$ \\
Status Pekerjaan & Perempuan & $24(32.4 \%)$ & $50(67.6 \%)$ \\
& $20-40$ & $14(25 \%)$ & $42(75 \%)$ \\
Jumlah Anak & $41-65$ & $12(41.4 \%)$ & $17(58.6 \%)$ \\
& Mahasiswa & $17(34 \%)$ & $33(66 \%)$ \\
& Bekerja & $0(0 \%)$ & $2(100 \%)$ \\
& Tidak Bekerja & $10(31.3 \%)$ & $22(68.8 \%)$ \\
& Tidak memiliki anak & $1(10 \%)$ & $9(90 \%)$ \\
& 1 orang & $4(26.7 \%)$ & $11(73.3 \%)$ \\
Penghasilan & 2 orang & $9(40.9 \%)$ & $13(59.1 \%)$ \\
& 3 orang & $9(37.5 \%)$ & $15(62.5 \%)$ \\
& 4 orang & $2(20 \%)$ & $8(80 \%)$ \\
& 5 orang & $2(40 \%)$ & $3(60 \%)$ \\
& $<$ Rp 2.717.750 & $2(15.4 \%)$ & $11(84.6 \%)$ \\
& $\geq$ Rp 2.717.750 & $23(35.9 \%)$ & $41(64.1 \%)$ \\
\hline
\end{tabular}

65 tahun sebanyak $12(41.4 \%)$.

Selanjutnya, berdasarkan status pekerjaan subjek juga lebih banyak mengalami control violence yaitu kelompok subjek yang tidak bekerja sebanyak 22 orang (68.8\%), subjek yang bekerja sebanyak 33 orang $(66 \%)$, dan subjek yang merupakan
2 orang (20\%) yang memiliki 4 anak, dan juga 2 orang $(40 \%)$ yang memiliki anak sejumlah 5 orang.

Berdasarkan jumlah penghasilan keluarga perbulan, subjek yang memiliki penghasilan di bawah dan di atas Rp 2.717.750,- keduanya lebih banyak 
mengalami control violence yaitu 11 orang $(84.6 \%)$ subjek yang memiliki pendapatan di bawah Rp 2.717.750,- dan sebanyak 41 orang $(64.1 \%)$ subjek yang berpendapatan di atas Rp 2.717.750,- subjek yang mengalami psycho-physical violence sebanyak 2 orang pada kelompok subjek yang memiliki pendapatan di bawah Rp 2.717.750., dan sebanyak 23 orang pada subjek yang memiliki pendapatan di atas Rp 2.717.750,-.

Uji asumsi dibutuhkan sebelum melakukan analisis data untuk uji hipotesis. Proses pengujian asumsi dilakukan sejalan dengan pengujian Crosstab dan Chi Square for Independent, sehingga penentuan terpenuhinya asumsi penelitian akan ditentukan setelah proses pengolahan data. Analisis data dapat dilakukan jika asumsi terpenuhi, yakni apabila bentuk tabel berukuran $2 \times 2$, maka tidak boleh ada satu cell yang memiliki frekuensi harapan (expected frequency) lebih rendah dari 5. Apabila bentuk tabel lebih dari $2 \times 2$, maka jumlah cell dengan frekuensi harapan yang berjumlah kurang dari 5 tidak boleh lebih dari 20\% (Pallant, 2010).

Tabel dalam penelitian ini terdiri dari 2 tabel dengan ukuran $2 \times 2$. Berdasarkan proses pengujian data, diketahui bahwa tabel tersebut dinyatakan memiliki cell dengan nilai frekuensi harapan di atas 5, yaitu nilai frekuensi harapan untuk tabel tingkat pendidikan dan bentuk kekerasan dalam rumah tangga sebesar 12.24, serta nilai frekuensi harapan untuk usia saat menikah dan bentuk kekerasan dalam rumah tangga sebesar 7.81. Oleh karena itu, dapat disimpulkan bahwa kedua tabel tersebut memenuhi uji asumsi dan dapat dilanjutkan untuk tahap analisis data.

Pengujian Crosstab dan Chi Square for Independent dilakukan untuk melihat perbedaan bentuk kekerasan dalam rumah tangga berdasarkan usia pada saat menikah dan tingkat pendidikan. Perbedaan bentuk kekerasan dalam rumah tangga ditinjau dari usia saat menikah dan tingkat pendidikan akan dijelaskan melalui nilai Asymp. Sig. (2sided).
Tabel 4

Nilai Signifikansi Usia saat Menikah dan Tingkat Pendidikan terhadap Bentuk Kekerasan dalam Rumah Tangga

\begin{tabular}{|c|c|c|}
\hline \multirow{2}{*}{ Variabel } & \multicolumn{2}{|c|}{$\begin{array}{c}\text { Bentuk Kekerasan dalam } \\
\text { Rumah Tangga }\end{array}$} \\
\hline & $\begin{array}{l}\text { Continuity } \\
\text { Correction }\end{array}$ & $\begin{array}{l}\text { Asymp. Sig } \\
\text { (2-sided) }\end{array}$ \\
\hline Usia Saat Menikah & .026 & .872 \\
\hline Tingkat Pendidikan & .014 & .905 \\
\hline
\end{tabular}

Berdasarkan tabel 4, dapat diketahui bahwa kedua variabel, baik usia saat menikah $(\mathrm{p}=.872)$ atau tingkat pendidikan $(\mathrm{p}=.905)$, menunjukkan nilai signifikansi lebih besar dari .05 ( $\mathrm{p}>.05)$. Dengan demikian dapat diartikan bahwa hipotesis penelitian yang diajukan dalam penelitian ini ditolak (ho diterima dan ha ditolak). Hasil ini menunjukkan bahwa tidak terdapat perbedaan bentuk kekerasan dalam rumah tangga ditinjau dari usia saat menikah dan tingkat pendidikan. Sehingga dapat disimpulkan perbedaan usia pada saat menikah dan tingkat pendidikan yang dimiliki subjek tidak berpengaruh terhadap bentuk kekerasan yang dialami. Subjek yang menikah pada usia muda atau lanjut dan subjek yang memiliki pendidikan rendah atau tinggi umumnya mengalami bentuk kekerasan yang sama yaitu control violence.

Penelitian yang dilakukan oleh Kidman (2016) yang dilakukan di 34 negara memerlihatkan bahwa tidak terdapat hubungan antara perkawinan pada usia dini dengan bentuk kekerasan pada pasangan di Eropa dan Asia Tengah. Penelitian ini juga menunjukkan tidak terdapat hubungan antara usia menikah yang lebih dewasa dengan kekerasan seksual terhadap pasangan. Hal ini disampaikan oleh peneliti kemungkinan berhubungan dengan tingkat yang sangat rendah baik pernikahan anak usia dini dan kekerasan seksual di wilayah tersebut. Hal serupa juga terlihat pada penelitian Vakili, Nadriah, Fathipoor, Boniadi, dan Morowatisharifabad (2010) bahwa tidak terdapat hubungan antara usia subjek saat menikah dengan bentuk kekerasan yang meliputi kekerasan fisik, kekerasan psikologis, dan kekerasan seksual. 
Hasil penelitian lainnya yang dilakukan pada 530 wanita yang telah menikah dan mengalami kekerasan dalam rumah tangga menemukan bahwa usia saat menikah dan tingkat pendidikan korban tidak berkorelasi dengan semua jenis kekerasan dalam rumah tangga yaitu kekerasan fisik, kekerasan psikologis, kekerasan sosial, dan kekerasan ekonomi (Pournaghash, 2011). Dalam penelitian Nikparvar dkk. (2018) diperoleh hasil bahwa variabel demografi yang di dalamya termasuk usia subjek saat menikah, usia pasangan saat menikah, tingkat pendidikan subjek, tingkat pendidikan pasangan, dan usia perkawinan tidak dapat memprediksi terjadinya kekerasan dalam rumah tangga dalam bentuk fisik maupun psikologis.

Hasil penelitian juga menunjukkan, ditinjau dari usia saat menikah dan tingkat pendidikan, baik subjek yang menikah pada usia 16-20 tahun (remaja) dan subjek yang menikah pada usia lebih dari 20 tahun (dewasa awal) hampir keseluruhannya mengalami control violence. Hal serupa juga terjadi dari tinjauan berdasarkan tingkat pendidikan subjek, baik subjek yang memiliki pendidikan tinggi dan pendidikan menengah, umumnya mengalami control violence yang mencakup kekerasan seksual, kekerasan ekonomi, dan kontrol paksa dibandingkan dengan psycho-physical violence yang berupa kekerasan psikologis dan kekerasan fisik. Hal ini menunjukkan bahwa perbedaan usia pada saat menikah dan tingkat pendidikan yang dimiliki subjek tidak berpengaruh terhadap bentuk kekerasan yang dialami, subjek umumnya mengalami bentuk kekerasan yang sama yaitu control violence. Penelitian Erten dan Keskin (2016) menyatakan rendahnya tingkat pendidikan berhubungan dengan meningkatnya kekerasan psikologis, kekerasan finansial, serta kekerasan fisik. Abolmaali dkk. (2014) secara lebih lanjut menyatakan bahwa control violence merupakan simbol pengontrolan yang berlebihan dan perilaku yang melarang pasangan untuk mengikuti berbagai kegiatan seperti pertemuan keluarga dan teman, termasuk pula mengontrol keberadaan pasangan, mengontrol komunikasi melalui telepon, pesan text, dan barang-barang pribadi pasangan, memaksa masalah ekonomi, dan hubungan-hubungan seksual. Sementara itu, tidak ditemukan perbedaan bentuk kekerasan pada subjek dengan latar belakang sosiodemografi seperti tingkat pendidikan, jenis kelamin, usia subjek, status pekerjaan, jumlah anak, dan penghasilan keluarga, subjek dengan setiap latar belakang sosiodemografi umumnya mengalami control violence. Salah satu bentuk dari control violence adalah kekerasan finansial atau financial control. Di tempat dimana kekerasan finansial sering terjadi, kekuatan hukum, finansial, dan pendidikan seharusnya dapat mengurangi kekerasan finansial (Kalokhe, Rio, Dunkle, Stephenson, Metheny, Paranjape, \& Sahay, 2017).

Kontrol paksa (coercive control) merupakan suatu perilaku yang mengarahkan kepada kekerasan psikologis dan fisik (Aizpurua, Copp, Ricarte, \& Vazquez, 2017). Salah satu penyebab terjadinya kontrol paksa adalah relasi kuasa yang sering terjadi pada masyarakat dengan budaya patriarki, termasuk Aceh. Berbagai kasus kekerasan dalam rumah tangga terjadi karena budaya patriarki yang masih melekat sebagai pola pikir masyarakat. Termasuk juga memberi legitimasi pada tindakan kekerasan yang dilakukan laki-laki kepada pasangannya. Budaya patriarki membenarkan laki-laki untuk melakukan kekerasan, pola pikir dimana laki-laki berkuasa atas perempuan, sehingga istri dituntut untuk menuruti semua keinginan suami, bahkan keinginan yang buruk sekalipun. Dalam budaya patriarki, kekerasan boleh saja dilakukan terhadap pasangan jika istri tidak menuruti perintah suami (Sakina \& Siti, 2017).

Jumlah kekerasan verbal, seksual, dan fisik dalam penelitian Gokler, Arslantas, dan Unsal (2014) di Turki yaitu sebanyak 38.4\% kekerasan verbal, $15 \%$ kekerasan seksual, dan 35\% kekerasan fisik. Lebih lanjut, Gokler dkk. (2014) menyatakan bahwa kemungkinan jumlah kekerasan seksual yang 
ditemukan dalam penelitian ini sedikit disebabkan oleh pengalaman seksual masih dianggap tabu dan memalukan bagi masyarakat Turki.

Kekerasan dalam rumah tangga menjadi suatu permasalahan kesehatan global yang menyebabkan psychological distress jangka panjang dan akut selain juga menyebabkan kecacatan fisik dan penyakit kronis (Davies, 2016; Perryman \& Appleton, 2016). Oleh karena itu, kekerasan dalam rumah tangga harus dicegah dan diatasi. Penelitian yang dilakukan oleh Jahromi, Jamali, Koshkaki, dan Javadpour (2016) menyatakan bahwa meningkatkan pendidikan laki-laki dan perempuan merupakan salah satu cara untuk mencegah kekerasan dalam rumah tangga. Laki-laki dan perempuan yang memiliki pendidikan yang baik juga memiliki kemampuan coping yang baik. Penelitian Shiraz (2016) juga menyatakan hal serupa, dimana pendidikan mempunyai peran yang positif bagi wanita Saudi Arabia dalam menurunkan tingkat kekerasan yang dialami.

Penelitian ini tentu jauh dari sempurna sehingga masih terdapat kekurangan, baik karena keterbatasan peneliti sendiri maupun dalam proses pelaksanaannya. Tantangan paling signifikan yaitu proses screening dalam menentukan kriteria yang spesifik untuk mendapatkan subjek yang mengalami kekerasan dalam rumah tangga yang dapat dilihat dari skor total kuesioner penelitian. Selain itu, lokasi dilakukannya penelitian di Kota Banda Aceh menyebabkan peneliti tidak dapat menemukan subjek yang memiliki tingkat pendidikan pada pendidikan dasar (yaitu memiliki pendidikan terakhir Taman Kanak-kanak atau Sekolah Dasar). Selain itu, peneliti juga kesulitan mendapatkan subjek yang menikah pada rentang usia 16-20 tahun, sehingga subjek penelitian lebih banyak yang menikah pada usia di atas atau sama dengan 21 tahun.

\section{Simpulan}

Hasil penelitian menunjukkan bahwa tidak terdapat perbedaan bentuk kekerasan dalam rumah tangga ditinjau dari usia saat menikah dan tingkat pendidikan. Artinya, subjek yang menikah pada usia remaja atau dewasa dan subjek yang memiliki tingkat pendidikan rendah ataupun tinggi mengalami bentuk kekerasan yang sama yaitu control violence. Berdasarkan hasil penelitian juga diketahui bahwa perbedaan latar belakang sosiodemografi lainnya seperti jenis kelamin, usia, jumlah anak, status pekerjaan, dan penghasilan yang dimiliki subjek tidak berpengaruh terhadap bentuk kekerasan yang dialami, subjek umumnya mengalami bentuk kekerasan control violence.

\section{Daftar Pustaka}

Abolmaali, K., Saberi, H., \& Saber, S. (2014). The construction and standardization of a domestic violence questionnaire. Sociology Mind, 4(1), 5157. doi.org/10.4236/sm.2014.41007

Aghakhani, N., Nia, H. S., Moosavi, E., Eftekhari, A., Bahrami, M., \& Nikoonejad, A. (2015). Study of the types of domestic violence committed against women referred to the Legal medical organization in Urmia-Iran. Iran J Psychiatry Behav Sci, 9, 1-6. doi: 10.17795/ijpbs-2446

Aizpurua, E., Copp, J., Ricarte, J. J., \& Vazque, D. (2017). Controlling behaviors and intimate partner violence among women in Spain: An examination of individual, partner, and relationship risk factors for physical and psychological abuse. Journal of Interpersonal Violence, 1-24. doi: 10.1177/0886260517723744

Anderberg, D., Rainer, H., Wadsworth, J., \& Wilson, D. (2015). Unemployement and domestic violence: Theory and evidence. The Economic Journal, 1-33. doi: 10.1111/ecoj.12246

Ashcroft, J., Deborah, D. J., \& Hart, S. V. (2004). Violence agains women: Identifying risk factors. USA: U.S. Department of Justice Office of Justice Programs. National Institute of Justice. 
Azwar, S. (2013). Penyusunan skala psikologi. Yogyakarta: Pustaka Pelajar.

Banerjee, A., Ferrara, E. A., \& Orozco, V. (2019). Entertainment, education, and attitudes toward domestic vilence. AEA Papers and Proceedings. 109(May 2019), 133-137. doi.org/10.1257/pandp.20191073

Bintang, R. (2018). Kasus kekerasan terhadap perempuan dan anak meningkat di Aceh, ini rincian tiap daerah. Serambinews. Diunduh melalui www.aceh.tribunnews.com pada $11 \mathrm{Mei}$ 2018

Dafeni, S. R., Mawarni, A., Nugroho, D., \& Dharmawan, Y. (2017). Hubungan beberapa faktor penyebab kekerasan dalam rumah tangga (KDRT) pada istri PUS di kelurahan Tinjomoyo kecamatan Banyumanik tahun 2016. Jurnal Kesehatan Masyarakat (e-Journal), 5(4), 256-264. Retrieved from http://ejournal3.undip.ac.id/index.php/jk m\%0AHUBUNGAN

Davies, R. A. (2016). Domestic violence and women's mental health. Cambridge University Press. doi: 10.1017/CBO9781107045132.015

Erten, B., \& Keskin, P. (2016). For better or for worse? Education and the prevalence of domestic violence in Turkey. 1-73.

Flake, D. F. (2005). Individual, family, and community risk markers for domestic violence in peru. Violence Againts Women, 11(3), 353-373. doi: $10.1177 / 1077801204272129$

Gokler, M. E., Arslantas, D., Unsal, A. (2014). Prevalence of domestic violence and associated factors among married women in a semi-rural areaof western Turkey. Pak J Med Sci, 30(5), 10881093. doi: 10.12669/pjms.305.5504

Hogan, K. (2016). Mens experiences of female-perpetrated intimate partner violence: A qualitative exploration. (Thesis). DCounsPsych, University of theWest of England.
Idrus, M. (2009). Metode penelitian ilmu sosial: Pendekatan kualitatif dan kuantitatif. Jakarta: Erlangga.

Jahromi, M., Jamali, S., Koshkaki, A., \& Javadpour, S. (2016). Prevalence and risk factors of domestic violence against women by their husbands in Iran. Global Journal of Health Science, 8(5). doi.org/10.5539/gjhs.v8n5p175

Kalokhe, A., Rio, C., Dunkle, K., Stephenson, R., Metheny, N., Paranjape, A., \& Sahay, S. (2017). Domestic violence against women in India: A systematic review of a decade of quantitative studies. Global Public Health, 12(4), 498-513. doi.org/10.1080/17441692.2015.111929 3

Kidman, R. (2016). Child marriage and intimate partner violence: A comparative study of 34 countries. International Journal of Epidemiology, O(0), 1-14. doi: 10.1093/ije/dyw225.

Komisi Nasional Perempuan. (2017). Lembar fakta catatan tahunan (Catahu) komisi nasional perempuan tahun 2017. Komisi Nasional Perempuan. Diunduh melalui www.komnas perempuan.go.id pada 10 Februari 2018.

Kompas.com. (2017). Lebih dari 700.000 pria di inggris jadi korban KDRT, 135 diantaranya tewas dibunuh. Kompas. Diunduh melalui http://aceh.tribunnews.com/2017/11/25/1 ebih-dari-700000-pria-di-inggris-jadikorban-kdrt-135-diantaranya-tewasdibunuh?page $=2$ pada 25 April 2018.

Lujeng, R., Sukohar, A., Hutaharuk, P., \& Putra, A. (2016). Kekerasan dalam rumah tangga pada kasus pernikahan dini. Jurnal Medula Unila, 6(1), 143148

Mantiri, S. I. E., Siwu, J. F., \& Kristanto, E. G. (2013). Hubungan antara usia waktu menikah dengan kejadian kekerasan dalam rumah tangga di Manado periode september 2012 - agustus 2013. Bagian Ilmu Kedokteran Forensik dan 
Medikologal RSUP Prof. DR. R. D. Kandou Manado.

Garcia-Moreno, C., Jonsen, H. A., Ellsberg, M., Heise, L., \& Watts, C. H. (2006). Prevalence of intimate partner violence: Findings from the WHO multy-country study on women's health and domestic violence. Lancet, 368(9543), 1260-9.

Nikparvar, F., Stith, S., Anderson, J., \& Panaghi, L. (2018). Intimate partner violence in Iran: Factors associated with physical agression victimization and perpetration. Journal of Interpersonal Violence, 1-19. doi: 10.1177/0886260518759060

Pallant, J. (2010). SPSS: Survival manual 4th edition. New York: McGraw Hill.

Papalia, D. E., Strens, H., Feldman, R., \& Camp, C. (2002). Adult development and aging. New York: McGraw Hill.

Perryman, S. M., \& Appleton, J. V. (2016). Male victims of domestic abuse. Oxford Brookes University.

Pournaghash, S. (2011). Domestic violence in Iran: A literature review. Elsevier, 16, 1-16. doi:10.1016/j.avb.2010.12.001

Pun, P. (2013). Empowerment of women through education to reduce domestic violence: A case study from Itahara, Nepal. (Thesis). Norwegian University of Life Sciences.

Sakina, A. I., \& Siti, D. A. (2017). Menyoroti budaya patriarki di Indonesia. Social Work Journal, 7(1). 71-80. ISSN: 2528-1577.

Shiraz, M. S. (2016). The impact of education and occupation on domestic violence in Saudi Arabia. International Journal of Social Welfare, 25(4), 339346. DOI: 10.1111/ijsw.12214

Sugiyono. (2013). Metode penelitian kuantitatif, kualitatif, dan $R$ \& D. Bandung: Alfabeta.

Wahab, R. (2006). Kekerasan dalam rumah tangga: Perspektif dan edukatif. UNISA, 29(61), 247-256.

Wiyarsi, A., Salirawati, D., \& Sulistyowati, E. (2012). Peran serta orang tua dalam pendidikan karakter secara normal.
Jurnal Penelitian Humaniora, 17(2), 115. 